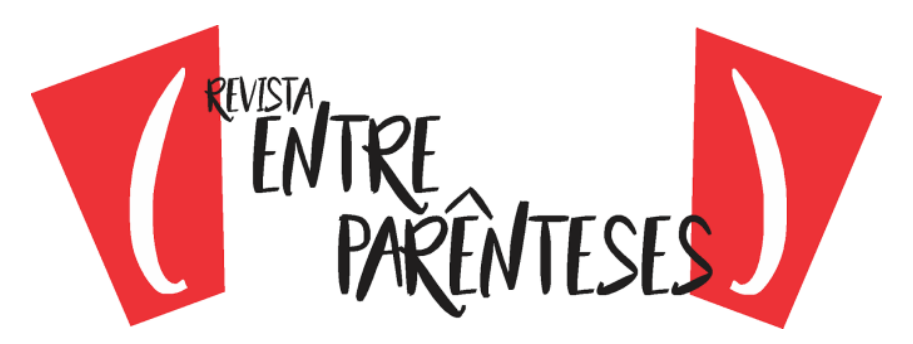

\title{
A REPRESENTAÇÃO DAS CLASSES POPULARES EM ZERO: QUESTÕES DE LEGITIMIDADE, AUTORIDADE E ALTERIDADE NA LITERATURA MARGINAL
}

\author{
Júlia de Mello Silva Oliveira ${ }^{1}$ \\ Universidade Federal de São Carlos - UFSCar (Capes DS) \\ (mellodeju@gmail.com)
}

\begin{abstract}
Resumo: O termo "Literatura Marginal", surge em meados das décadas de 60/70 com um grupo de escritores à margem/fora do cânone e, por isso, à margem/fora do sistema de produção, circulação e distribuição das editoras. Já nesse período havia ainda outros escritores marginais, assim chamados porque representavam, em suas obras, as classes pobres. Esses últimos escritores, embora denunciassem em seus textos a situação do pobre naquele período da ditadura militar, não eram, eles próprios, integrantes dessa parcela da sociedade. Desde há muito, aliás, diversos autores, não pertencentes às classes mais pobres, escreveram uma literatura que denunciasse essa realidade. $O$ descompasso, o de uma literatura escrita por autores que não eram oriundos do grupo sobre o qual escreviam, é o problema redefinidor da Literatura Marginal hoje, o que se dá sob a problemática da alteridade, fortemente discutida pela crítica atualmente, na qual estão imbricadas questões de legitimidade da representação e autoridade do escritor. No entanto, essa mudança não tira ou diminui o valor da literatura dos primeiros marginais, dado que o texto literário se constitui a partir de seu efeito mimético-representacional, o qual sempre será relativo, dando apenas uma ou algumas versões do real representado: é o que se verá a partir da análise de Zero.
\end{abstract}

Palavras-chave: Literatura Marginal; Alteridade; Representação; Zero.

Abstract: The term "Marginal Literature" emerged, approximately, in the middle of sixty or seventy decades in Brazil, with a group of writers known as "Mimeograph Generation", marked by its exclusion from the canon and, therefore, also from the publishing, circulation, and distribution system: canonically and editorially marginalized. There was, also in this period, other peripheral group of writers named "Marginal", for they represented in their books poor classes. These last kinds of writers, although they denunciate, in their texts, the poor classes situation at Brazilian dictatorial government, weren't themselves part of the social group thematized on their plot. This wasn't, in fact, the first time when writers who didn't belong to the poorest classes wrote a literature that denounced this reality, however this apparent problem redefined actual or contemporary Marginal Literature. This redefinition occurred under the alterity subject, strongly discussed by critics today, in which are interwoven questions about representation's legitimacy and writer's authority. This Marginal Literature's changes on meaning, from sixties to the present day, don't decay the literature's value of the first marginal writers since literary text is constituted, it-self, by mimetic-representational effect that is always relative, offering just real-represented versions. That is what will be demonstrated in this article with the analyses of a Ignacio's de Loyola Brandão novel, titled Zero.

Keywords: Marginal Literature; Alterity; Representation; Zero.

Resumen: La denominación "Literatura Marginal", surge en mediados de las décadas de 60/70 con un grupo de escritores a la margen/fuera del canon y, por este motivo, a la margen/fuera del sistema de

1 Graduada (Licenciatura e Bacharelado) em Letras pela Universidade Federal de Alfenas, Unifal-MG. Mestranda no Programa de Pós-Graduação em Estudos de Literatura (PPGLit) da UFSCar. Bolsista Capes DS (no do processo: 1692060). 


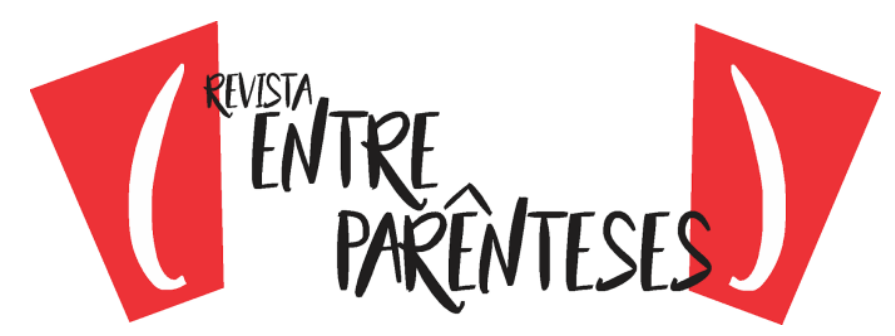

producción, circulación y distribución de las editoriales. Ya en este periodo había, todavía, otros escritores marginales, así llamados porque representaban, en sus obras, las clases pobres. Estos últimos escritores, aunque denunciaran en sus textos la situación del pobre de aquel periodo de la dictadura militar, no eran, ellos propios, integrantes de esa parcela de la sociedad. Desde hace mucho, incluso, diversos autores, no pertenecientes a las clases más pobres, escribieron una literatura que denunciaba tal realidad. El descompás, el de una literatura escrita por autores que no eran oriundos del grupo sobre el que escribían, es el problema "redefinidor" la Literatura Marginal hoy, que se da bajo la problemática de la alteridad, fuertemente discutida por la crítica actualmente, en la cual están imbricadas cuestiones de legitimidad de la representación y autoridad del escritor. No obstante, ese cambio no quita o disminuye el valor de la literatura de los primeros marginales, dado que el texto literario se constituye a partir de su efecto mimético-representacional, que será siempre relativo, dando solo una o algunas versiones de lo real representado: es eso lo que se verá a partir del análisis de Zero.

Palabras-clave: Literatura Marginal; Alteridad; Representación, Zero.

\section{Introdução}

Existe toda uma problemática que envolve o que hoje se entende por Literatura Marginal em face do que ela era quando de seu surgimento no cenário da literatura brasileira. Isso porque a Literatura Marginal de origem se diferencia significativamente da Literatura Marginal Contemporânea em razão de questões que dizem respeito à legitimidade da representação das classes populares, considerada a questão da autoria, da autoridade que teriam os autores para falar em nome dessas classes, o que seria, também, questão própria à representação da alteridade.

O termo "Literatura Marginal" aparece, pela primeira vez, para cunhar o tipo de produção literária que faziam os poetas da Geração Mimeógrafo, na década de 1970, auge da ditadura militar brasileira. Tal grupo estava à margem do mercado editorial (a Indústria Cultural e a bestsellerização os levou a mimeografa/manufaturar suas obras e distribuí-las ao público, a contrapelo da dinâmica de mercado cultural emergente) e do cânone literário (a crítica, majoritariamente, definiu sua literatura como menor porque "sentimentaloide", restrita à esfera do particular e do íntimo). Concomitantemente a essa Geração, havia uma outra postura literária também considerada marginal: aquela em que os escritores se empenharam em "representar os setores mais baixos da sociedade - ainda que não sejam eles mesmos marginais" 


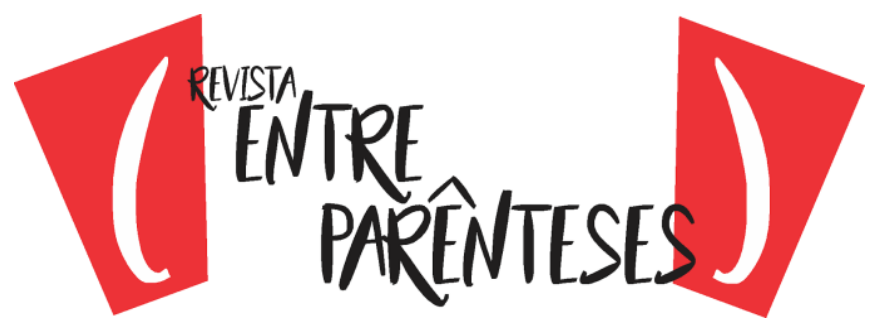

(PATROCíNIO, 2013, p. 29) -, falando sobre o pobre e pelo pobre. O papel desses escritores, porém, foi desempenhado na medida em que apresentou "sua produção enquanto ferramenta de uma denúncia da condição de vida dos excluídos do milagre [econômico]" (Id., 2013, p.29). Ressalte-se que esta postura não era inédita e muito menos típica da época. Ao menos desde o século XIX, com $O$ cortiço, já existem obras que possibilitam discutir essas questões, mas é nas décadas de 1960 e, principalmente, de 1970/1980, que a identificação do escritor com as classes marginalizadas parece começar, gradativamente, a ser questionada. Enfoquemos, pois, tal questionamento.

Gonzaga (1981, p.149) divide em três grupos os escritores da década de 1970: os marginais da editoração, da linguagem e os que falam sobre e pelos marginalizados. Segundo o autor (id., p.147-148), os marginais da editoração seriam os excluídos do mercado editorial e seus padrões, os que eram contra o incentivo do milagre econômico à Indústria Cultural, bem como à importação dos best-sellers - eram os da geração mimeógrafo, os das cooperativas de escritores (comuns em Curitiba e Porto Alegre) e aqueles que participavam de revistas, jornais e suplementos literários. Já os marginais da linguagem seriam os escritores brasileiros herdeiros das vanguardas, ou seja, os que adotaram uma postura de recusa de uma linguagem institucionalizada e do poder dominante. Por último, o grupo de escritores marginais que falava em nome dos excluídos dos benefícios do milagre, tornando-os objetos para representações de angústias sociais no espaço da literatura, servindo esta como instrumento de comprometimento social e denúncia.

Para legitimar o tipo de elocução desse último grupo que falava em lugar do outro, Flora Sussekind (1985, p.58) chama a atenção para o fato de ter sido necessário se construir uma imagem para esse locutor, próxima à realidade daqueles em lugar de quem ele fala. Assim, ela (id., 1985, p. 43-66) diz sobre uma "Literatura Verdade" que teria o compromisso de dizer a "verdade" por quem não pode; que teria a função de resistir, denunciar e se rebelar não apenas por si, mas, também, por quem não pôde fazê-lo. Por meio, então, de uma literatura irmanada com o jornalismo, a qual 


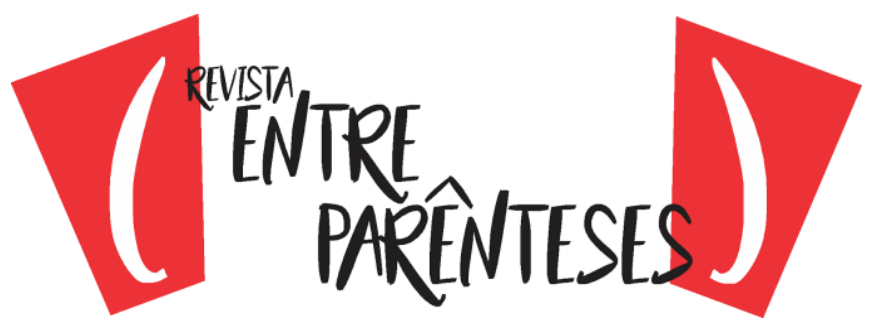

falava de um Brasil que a censura não permitia mostrar, o escritor assumia o papel de reportar, de informar, de dizer sobre sua própria condição e sobre a de quem não tinha condição de fazer o mesmo, adquirindo "uma imagem que oscila entre a marginalidade semelhante à dos personagens que representa e o heroísmo de um 'Robin Hood' de classe média que se imagina sempre ao lado dos 'fracos e oprimidos'" (SUSSEKIND, 1985, p.58).

Ana Cristina Cesar (1999, p. 207), ainda, em "Malditos marginais hereges", põe em xeque a postura desses escritores, questionando a forma pela qual puderam se apresentar como porta-vozes de grupos minoritários, sem se questionarem acerca do "poder" que teriam para falar sobre e em nome desses grupos emudecidos, de refletilos/interpretá-los ou de levar à classe média certa conscientização sobre sua responsabilidade em relação a esse silêncio. Por isso, ela diz: "o intelectual de esquerda ainda é o sujeito que tem ideias, opiniões, inclinações revolucionárias, mas que não consegue repensar revolucionariamente o próprio trabalho". O puxão de orelha é completo e Cesar termina seu texto propondo:

Esses operários banguelas, mendigos, desdentados, pingentes desajustados, policiais truculentos, soldados lesados, homossexuais e prostitutas escorraçados, prisioneiros torturados, etc., como quer o João Antônio, são aqui mal ou bem pessoas sociais dos novelistas, e não as pessoas reais da sociedade. A distância que vai de umas a outras é a distância (não moralizável) da mediação literária e a distância (indisfarçável, apesar da nossa culpa) entre os produtores/leitores de literatura (...) e "as massas populares" (CESAR, 1999, p. 211-212).

Apesar disso, esses que falam dos e pelos marginalizados, em tom de denúncia e como forma de resistência à repressão política, econômica, cultural, e social, tiveram sua escrita marcada por uma certa tentativa de circunscrever "a verdade", de "relatar e retratar sujeitos/personagens em condições inenarráveis à grande imprensa" (PATROCÍNIO, 2013, p. 29). A crítica, aliás, imediata à estreia dos textos desses autores, tratou logo de caracterizar suas obras - sobretudo contos e romances - de "realistas", assim o fazendo em razão do tom de denúncia social, de 


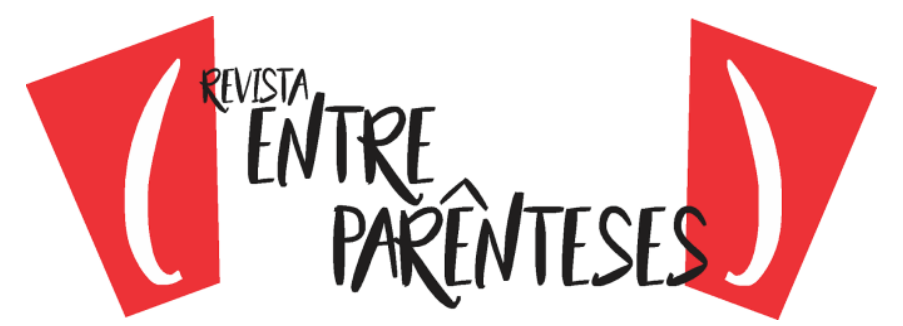

crítica à política, à economia, à ideologia, por causa de seu aspecto documental e memorialístico que estreita as relações com o período o qual colocam em perspectiva e em xeque. Patrocínio (2013, p.29), aliás, não deixa de considerar esse tom "realista" como uma postura que é, também, política, já que a escrita denuncia ao ficcionalizar a periferia, a margem.

A despeito de tudo isso, de toda essa discussão, explica-se, portanto, por que Bosi (2002, p. 257-261) fala que há, em geral, "duas maneiras de considerar a relação entre a escrita e os excluídos": uma que tem o excluído social, os marginalizados, como objeto da representação literária, i.e., como tema ou enquanto personagem, e outra que não toma o marginal como objeto, que não fala dele e por ele, mas que o centraliza como sujeito autor desse processo simbólico.

Esta última abordagem consiste no modo como a Literatura Marginal aparece na contemporaneidade. Em "Terrorismo Literário", texto de Ferréz (2005, p.12), publicado originalmente na revista "Caros Amigos", define-se: "A literatura marginal, sempre é bom frisar, é uma literatura feita por minorias, sejam elas raciais ou socioeconômicas. Literatura feita à margem dos núcleos centrais do saber e da grande cultura nacional, isto é, de grande poder aquisitivo". Em outras palavras, a Literatura Marginal Contemporânea é aquela feita pelo sujeito morador da favela, do gueto, do morro, da comunidade, da margem. É o espaço em que esse sujeito exerce o direito de falar de seu lugar com o seu olhar e de se autorrepresentar simbólico-literariamente.

Aliás, no caso dos autores contemporâneos, segundo Patrocínio (2013, p.32), "a marginalidade não é apenas uma marca passiva que se fixa no sujeito, um desígnio social que nunca será rompido ou obliterado, mas sim uma posição que estabelece o sujeito fora de um centro, com o qual este mantém relações orgânicas e dinâmicas". Ou seja, o escritor marginal de hoje está fora do espaço literário hegemônico, mas integra um movimento - político - para que seja reconhecido dentro dele. 


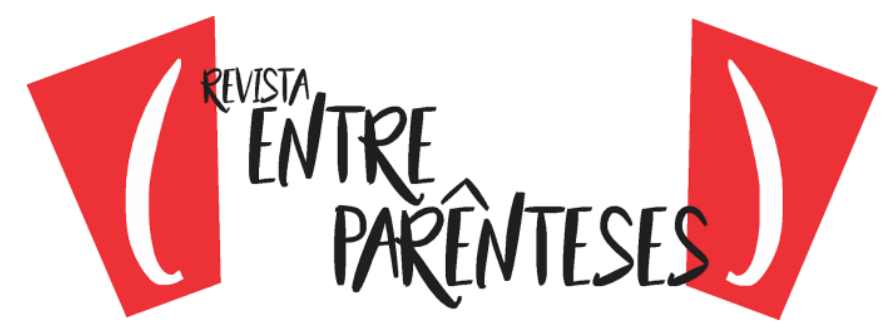

Daí João Cezar de Castro Rocha (2006, p.31) falar sobre a transição de uma "dialética da malandragem" (noção inspirada no texto célebre de Antonio Candido sobre "Memórias de um sargento de milícias") para o que ele chamou de "dialética da marginalidade". Essa transição significa que a literatura marginal contemporânea já não assume para si a antiga dicção que harmoniza e concilia as diferenças e os diferentes na representação literária. Ao contrário, essa nova literatura marginal - e nisso consiste o termo cunhado por Castro Rocha (id., 2006, p.56) - violentamente se impõe e irrompe por meio da representação do confronto, do conflito que leva à desigualdade social, à desigualdade de classes, embora a malandragem e a marginalidade, segundo o autor, ainda disputem a construção simbólico-literária do país. Essa nova dialética só é possível quando o marginal assume o controle da própria imagem e passa a expressarse com sua própria voz, i.e., quando ele se torna autor das representações literárias: permite-se ao marginal "projetar sua voz, a fim de articular uma crítica inovadora das raízes da desigualdade social" (id, 2006, p. 52). Trata-se, portanto, de ouvir o sujeito que vive a desigualdade e sofre seus efeitos, e não quem a observa e sente por ele.

Estamos falando, portanto, de uma literatura que assume uma dicção também marginalizada em relação ao chamado cânone literário. Isso porque trata-se de um texto que se caracteriza por possuir um discurso que tematiza as contradições do sistema, as várias formas de miséria e de violência por meio de uma linguagem também violenta, mas com um certo didatismo no tom, fazendo predominar, muitas vezes, os aspectos éticos em detrimento dos estéticos. Tratam-se de características que fazem com que grande parte da crítica tome esse texto marginal como não literário ou como uma literatura inferior. Por esse motivo, Adélcio de Sousa Cruz (2009, p.16-26) chama essa literatura insurgente de "literatura ruidosa" na medida que, em resposta aos espaços hegemônicos, ao cânone, ela se impõe numa postura político-identitária de resistência, fazendo ruído onde se queria silêncio, quando se queria o silêncio dos subalternos. 


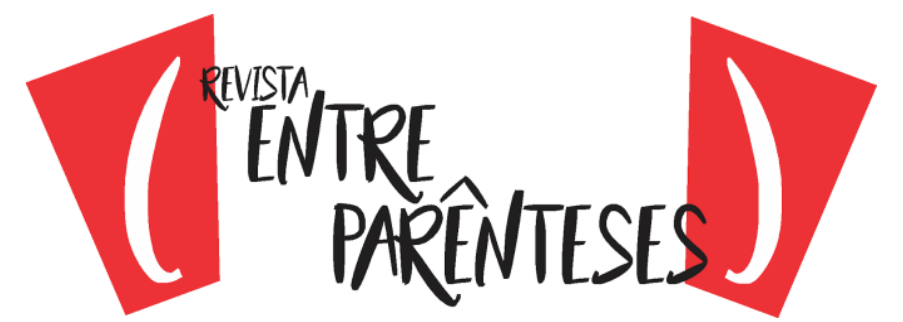

Por isso a redefinição contemporânea que houve em relação ao que se entendia por Literatura Marginal nos anos 1970 foi relevante. Porque, nessa época, não se considerava que os anseios dos escritores os quais se intitulavam marginalizados eram infimamente menores que os problemas, as injustiças, as violências, as misérias e a falta de voz dos marginais de verdade, embora se considere muitíssimo significativo que tenha havido uma preocupação com essa situação dos excluídos e uma postura de denúncia do problema como forma de lutar com e por eles. No entanto, conforme pontua João Cezar de Castro Rocha (2006, p.30) existem implicações éticas ao se "falar em nome dos que sofreram, em vez de fornecer-Ihes condições de contarem as suas próprias histórias". Questiona-se, então, junto de Gonzaga (1981, p.151), até que ponto "falar em lugar do outro" não seria apropriação de um discurso que, por não pertencer ao apropriador, faz dele um representante sem autenticidade na representação e sem legitimação para fazê-la.

Não apenas essa postura poética, mas também teórica (uma vez que a Literatura Marginal Contemporânea passou a surfar na crista da onda da crítica atual) é interessante e substancial para uma tentativa de se renovar o que se pode ser, o que se permite ser e o que é, em si, Literatura. No entanto, chama a atenção o fato de que toda taxonomia é limitada na medida em que um conceito nem sempre dá conta de tudo que ele intenciona abarcar. Há sempre elementos que dele escapam...

Dizemos isso porque diante de todo o percurso por nós traçado e do delineamento dos principais problemas que enfrenta e enfrentou a Literatura Marginal, resta, ainda, fazer mais uma reflexão. Esta reflexão faltante é mote do presente artigo o qual, por meio de uma análise de "Zero" (1975), de Ignácio de Loyola Brandão, pretende mostrar que embora a questão do "lugar de fala" seja, de fato, um ponto a se levar em consideração nas discussões sobre literatura, não se pode limitar a expressão literária a essa questão, ou seja, não se pode, a partir dela, ser radical no sentido de diminuir o valor de um texto porque o ponto de vista não foi expresso de dentro do espaço representado. Considerando a origem social de classe média do escritor, é 


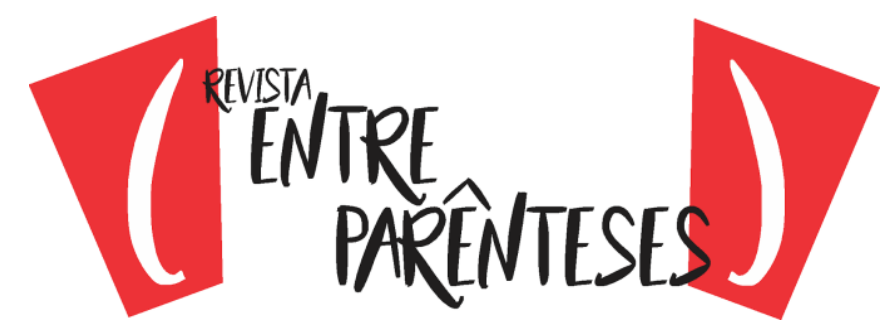

possível que ele assuma, literariamente, um olhar "subalterno", ponto de vista dos marginalizados a ser representado, de modo esteticamente eficiente, no plano da linguagem.

Mais especificamente, "Zero" é um romance pós-64, lançado no Brasil em 1975, mas censurado e liberado para circulação apenas em 1979, após a amenização da censura. Escrito por alguém da classe média que, ante a categorização de Gonzaga, pode ser considerado um herdeiro dos marginais da linguagem, bem como é um marginal porque fala sobre e pelos marginalizados, não deixa de ser um texto que traz os oprimidos pela violência do sistema, da desigualdade, da miséria, por meio de uma linguagem também violenta que, esteticamente trabalhada, não se sobrepõe às questões éticas que envolvem a situação dos operários, dos subempregados, dos trabalhadores informais, dos excluídos do milagre econômico.

Regina Dalcastagné (1996, p. 15-44), em "O espaço da dor: o regime de 64 no romance brasileiro", traça relações entre romance, realismo, engajamento e o papel do artista/escritor na sociedade. Para tanto, evoca a antiga discussão teórica sobre a capacidade da literatura de colocar a realidade em perspectiva, especialmente quando sob a forma romance: "gênero universal e sem regras, que rompeu normas, absorvendo os meios técnicos do teatro, da poesia e do jornalismo, passeando pela história, pela política, pela economia e pela moral, (...) mostrou desde muito cedo seu enorme poder de inserção social" (1996, p.18-19). Nesse sentido, a estudiosa acaba reconhecendo caráter político e engajado (não panfletário) da literatura dos anos 1960, dizendo que esse aspecto vincularia a obra a seu tempo por meio da denúncia, da contestação, da crítica, do documental. O fato é que, segundo a pesquisadora, essa literatura reafirmou o constructo de uma imagem nacional e de um povo, ressaltando os perigos da dominação das classes de poder, do imperialismo, para além das arbitrariedades políticas, econômicas e sociais do Estado e seus comparsas, sendo o romance o meio mais adequado e eficaz para a descoberta e interpretação da realidade. Por isso pairava sobre a classe de artistas/escritores o "espírito missionário" de conscientizar 


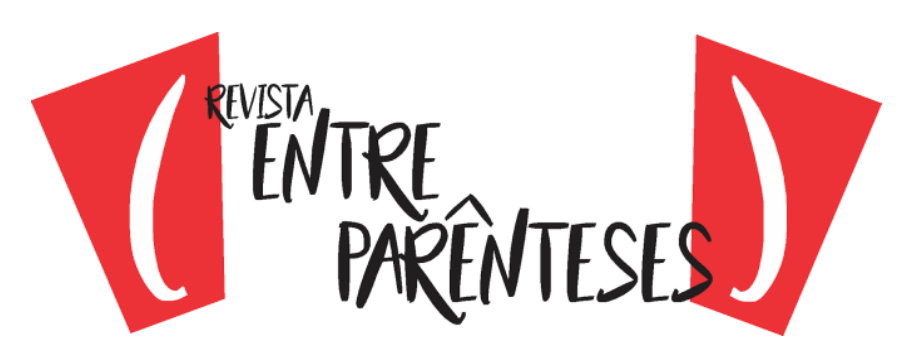

seu público por meio de suas criações. Projeto que, imediatamente, teria se visto frustrado exatamente porque sua menor tentativa trouxe à tona o problema da alteridade:

Outros nomes importantes também fizeram a revisão crítica do CPC [Centro Popular de Cultura da União Nacional dos Estudantes] e de sua arte engajada, entre eles Oduvaldo Vianna Filho, que condenava o naturalismo e a falta de profundidade dos artistas, confessando que 0 que se fazia era um "pronto-socorro artístico". Ao mesmo tempo, ele lembra que a experiência do CPC serviu muito mais aos seus integrantes do que àqueles a quem se destinava. Querendo ensinar, estudantes e artistas saíram aprendendo. Aos poucos, o contato com o povo, com a realidade do interior do país foi desenhando alternativas menos autoritárias. Exemplo desse confronto entre o saber dos artistas e as reais necessidades do povo, a quem ele se dirigia, está numa das histórias que Augusto Boal conta sobre a investida do CPC junto ao campesinato brasileiro.

Numa interpretação teatral no Nordeste, os atores cantavam com entusiasmo uma música que dizia que "derramemos o nosso sangue para defender a terra". Ao final do espetáculo um camponês aproxima-se emocionado e diz que é aquilo que tem de ser feito. Os atores sentem, felizes, que conseguiram passar sua mensagem. $O$ camponês explica que está havendo uma invasão e os convida a tomarem seus fuzis e se juntarem à luta. Eles, aterrorizados, explicam que os fuzis são de mentira. O camponês diz que tudo bem, que os fuzis são de mentira mas que os homens são de verdade, que ele tem os fuzis para lhes dar. Constrangidos, os atores explicam que são artistas e que não vão lutar. O camponês entende e completa: "Ah, então quando vocês falavam em derramar o nosso sangue, era do nosso sangue que estavam falando".

Essa história caracteriza bem o desenvolvimento de um conflito de identidade entre os artistas, um conflito que não poderia deixar de surgir quando um bando de jovens de classe média decide "ser povo". (DALCASTAGNÉ, 1996, p. 39-40).

A partir dessa reflexão, Regina Dalcastagné (1996, p. 40) ressalta que "esse 'sair ao encontro do povo', com todos os erros que lhe podem ser imputados, teve, por esse lado, seus méritos": o artista teve de repensar sua trajetória desfrutando do aprendizado com o outro, respeitando a diversidade social, lançando novo olhar sobre o Brasil porque olhou para o povo de verdade (mal visto, desfocado, mas entrevisto: os problemas do campo, os da cidade e da industrialização). Por essa perspectiva, ainda 


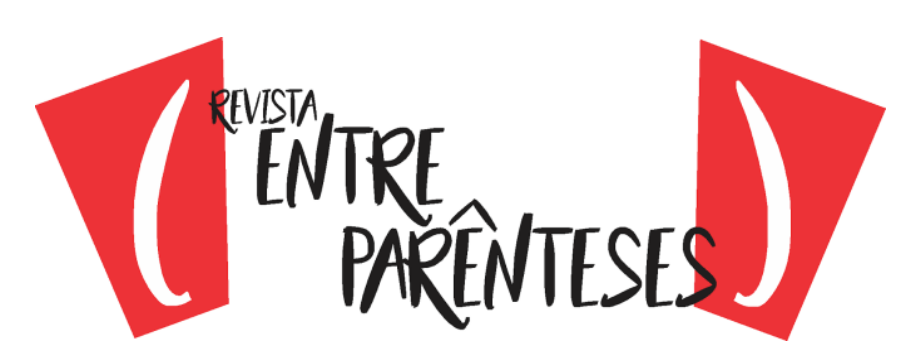

que haja um conflito identitário envolvido no processo da escritura, esteve em jogo um movimento de transformação que culminou em "novas maneiras de ver, pensar e fazer a arte e a política" (id., 1996, p. 41). Isso porque o artista aprendeu mais com o povo do que o contrário: "Lá, onde ele acreditava existir apenas a miséria e uma força bruta pronta a ser moldada por seu discurso 'conscientizador', ele encontrou um mundo extremamente complexo, muito mais profundo do que suas pecinhas didáticas poderiam supor" (id., 1996, p. 41). Encontro esse que espelhou a imagem do próprio artista, fazendo-o repensar a si e sua posição autoritária, a ingenuidade de seu olhar diante do que havia encontrado e a necessidade de ir a fundo na problematização das questões descobertas, mais, até, do que o próprio momento possibilitaria (id., 1996, p. 41-42). Aprofundar-se significava, também, adotar uma postura democrática, respeitosa em face às diferenças e particularidades do outro (id., 1996, p. 41), mas, acima de tudo, reconhecedora da legitimidade do conflito na sociedade: talvez tenha sido ali, na década de 1960 que se deu esse primeiro passo em direção à democracia, para além da luta contra o regime ditatorial (id., 1996, p. 42).

Dessa forma, Patrocínio (2013, p. 55-64) elenca como principais características da nova Literatura Marginal: 1) a denúncia e o exame crítico da periferia que também funcionam como agenciamento político do leitor; 2) a potencialidade política do texto; 3) a representação da violência física e social; 4) a despretensão de ser moral; 5) o tom de testemunho; 6) o valor coletivo do enunciado; 7) o efeito pedagógico; 8) o retrato do cotidiano da comunidade; 9) a presença de um sentimento de vingança contra o sistema, contra os autores da desigualdade social e contra os produtores da miséria; 10) a existência de um princípio ético regulador que enfoca mais a apresentação do tema em detrimento de um trabalho e/ou preocupação estéticos. Quando se analisa o texto de "Zero", encontra-se nele muitos dos aspectos elencados como definidores dessa Literatura Marginal de hoje, embora seu enunciador não o tenha escrito enquanto morador da periferia. É o que passaremos a problematizar. 


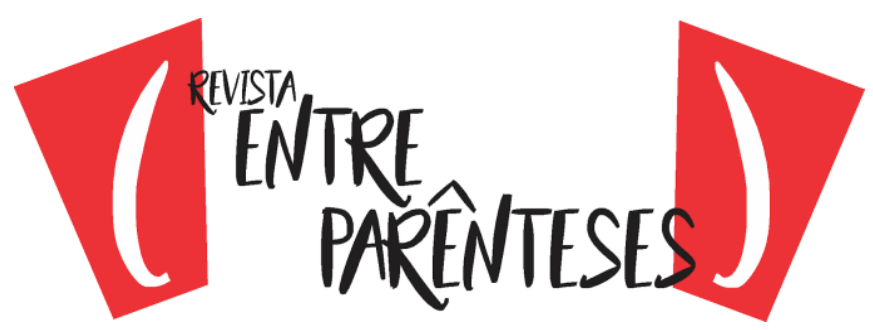

O contraponto zero: de volta às origens.

Ignácio de Loyola Brandão nasceu em Araraquara num contexto familiar relativamente pobre. Jornalista, roteirista, admirador/estudioso/crítico de cinema, escritor, viveu, desde aproximadamente seus 21 anos em São Paulo, trabalhando. "Zero", um de seus romances mais famosos, foi escrito ao longo da década de 60. Embora tenha sido escrito por um autor que não era marginal, no sentido contemporâneo, trata-se de um romance que possui várias (senão todas) as características da Literatura Marginal Contemporânea, apesar da ausência do que se poderia chamar de "lugar de fala".

"Zero" é uma narrativa de narrativas. Não há um centro, um núcleo dramático para o qual convirjam os episódios narrados. Ao mesmo tempo em que se narra a história de José, narra-se, indiretamente, por meio da construção ficcional enleada no enredo, a ditadura militar brasileira, a guerrilha, a luta armada, a tortura, o milagre econômico, o progresso, o crescimento urbano, o imperialismo, o consumismo, a expansão da mídia e da indústria cultural, a alienação, o pensamento pequeno burguês; ao mesmo tempo em que se narra a história de José, narram-se histórias de professores, pesquisadores, cientistas forçados a deixar o país por causa da repressão; narra-se a onda migratória de pessoas em busca de melhor qualidade de vida em uma nação promissora; narra-se a história do faquir, de Carlos Lopes (e a tentativa de conseguir um atendimento hospitalar para o seu filho doente, lutando contra as burocracias do regime), da ascensão e do fim do Boqueirão, dos operários e trabalhadores, do desemprego, da exploração capitalista, da violência, da miséria e da pobreza resultantes de todo esse cenário de contrastes e contradições. Seu espaço: uma cidade grande de um país da nomeada, no livro, América Latíndia. Seu tempo: algo em torno das décadas de 60/70, durante o auge do governo militar.

Narrativa de narrativas porque cada uma dessas histórias tem seus pedaços sendo contados pouco a pouco, à medida que cada trecho de cada uma vai se 


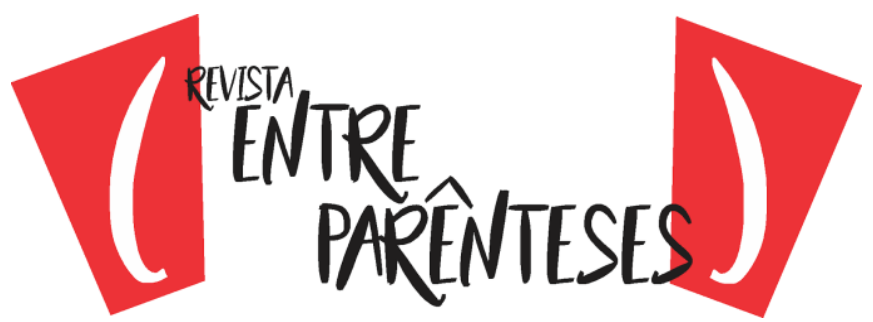

intercalando com os trechos das demais histórias. Os fragmentos de cada narrativa se alternam. O leitor vai tomando contato com cada trecho/fragmento e, à medida que sua leitura progride, vai juntando os pedaços de cada narrativa, até que alcance certa noção da situação envolvida em cada uma delas. Esses fragmentos, aliás, que informam tais narrativas são pedaços de textos, panfletos, propagandas, trechos de música, títulos de filme, proclamações radiofônicas do governo na hora oficial, determinações oficiais por escrito, trechos de depoimentos dados sob tortura, imagens, gráficos, formas geométricas, textos jornalísticos, orações, inscrições de privada, pensamentos do dia, adivinhas, ditados populares, receitas, etc. e etc. Ou seja: trata-se de um romance estruturado a partir de um falatório, de uma alternância de vozes ficcionais e ficcionalizadas (em primeiras e terceiras pessoas, misturadamente) que enformam ideologias e perspectivas subjetivamente diferentes sobre tempo e espaço, suas características, seu povo, economia, política, seus contrastes e contradições, simbolizando, ficcionalmente, por meio das narrativas dessas vozes, o que acontecia naquele momento da ditadura militar no Brasil, principalmente em relação aos que foram excluídos do Milagre Econômico e relegados ao esmo de sua própria miséria.

Dentro desse emaranhado de narrativas há uma preponderante que está envolvida em e por todas: a narrativa de José, o "infra-herói" do livro (BRANDÃO, 1986, p. 206), um matador de ratos "num cinema poeira" (id., 1986, p. 11), que sabia que o emprego estaria ameaçado quando tivesse "exterminado todos os bichos" (id., 1986, p.12). Zé morava, em uma cidade grande da América Latíndia, numa pensão e, posteriormente, vai morar com Átila, seu amigo, em um depósito de livros. Atila é borracheiro e trabalhava de motorista, levando turistas e curiosos para conhecer 0 acampamento dos sermoneiros que, ao irem embora, colocam fim, também, ao emprego de Átila. Ficam os dois desempregados num contexto em que não havia emprego disponível.

? E agora, Átila. Eu sem emprego, você também. 


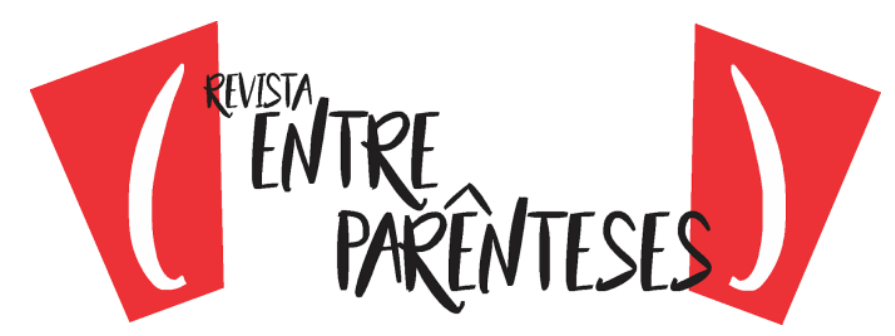

. A gente se vira. Calma, que se vira. O negócio é esse, hoje em dia. Emprego, emprego, nem tem, nem eu quero.

. Mas eu quero. Fico nervoso, sem emprego. Me dá uma coisa esquisita. (id., 1986, p. 32)

"Zero", para além de toda a conjuntura das décadas de 60 e 70 (política externa, interna, repressão militar, tortura, indústria cultural, etc.), narra a vida de subpessoas que vivem de subempregos e recebem subsalários, num cenário contrastante de concentração de renda nas mãos da tecnocracia-exploradora - "chefes adoram explorar (p. 19) - do trabalhador e redutora deste à condições infra-humanas.

O senhor é bom, mas volte em outra oportunidade. Entrevistas, testes. José pega a fila, dez, treze horas na fila que corre em volta do quarteirão. As filas aumentam. Os jornais: é o desemprego, a política de contenção. Indústria e comércio não admitem, demitem.

Entrevistador da TV: ? Por que não há mais empregos.

O industrial: Não é culpa nossa, andamos com a corda no pescoço, os bancos não financiam, o governo não empresta, têm os novos impostos as taxas de produção, o auxílio para combater o comunismo dentro da igreja, as cotas para as ligas de defesa da democracia, da moral, do civismo, o dinheiro gasto em bandeiras, em plástico para carros com dizeres cívicos, Ame ou Deixe Sua Terra, os etc, etc, etc, etc, etc, etc, etc, etc, etc, etc.

Esmolas, mendigos, fome, vendedores ambulantes surgindo por toda a parte. Advogados bem falantes vendendo io-iôs luminosos, ratinhos de corda, barbatana, esferográficas ( 3 por mil), saquinhos de limão (1 dúzia por 50 centavos), imagens de santo, bolas de gás, isqueiros, doces feitos em casa, perfumes, livros clandestinos (...). Médicos vendendo flâmulas de porta em porta. Agrônomos lavando vidros de carros nos estacionamentos. Arquitetos orientando construção de barracos nas favelas.

As filas no serviço social, crescendo. Brigas todas as noites diante dos albergues, debaixo dos viadutos, pontes, nas portas de prédio, portas de igreja / os mais fortes tomando o lugar e vendendo aos mais fracos por um cigarro, um dar a bunda, uma pinga e os padres surgindo com a polícia: fora, fora da casa de deus, ó vendilhões /, um lugar para dormir. Mendigos, vagabundos, desempregados, hordas revirando os lixos da cidade, de todas as cidades. As casas invadidas, ladrões presos ao roubar dispensas, armazéns e supermercados protegidos por contingentes policiais. Todo mundo querendo ir para cadeia onde, ao menos, não se morre de fome (id., 1986, p. 132-133). 


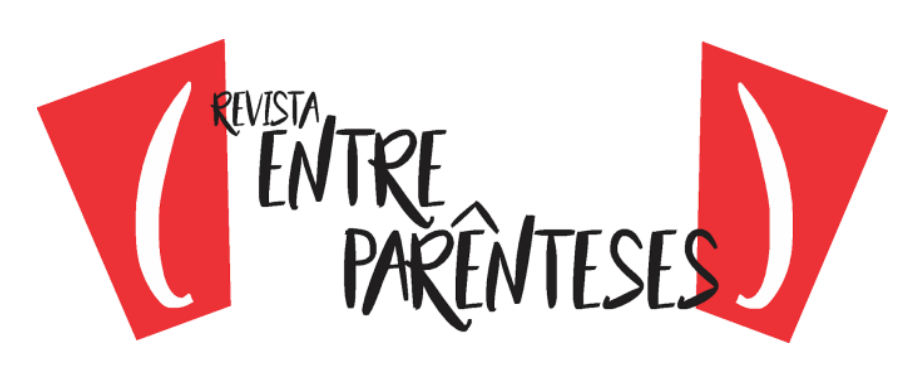

Ao longo do romance, José pula de emprego em emprego: além do cinema, trabalhou numa "firma de representações comerciais, exportação e importação" (id., 1986, p. 45), trabalhou na Coca-Cola fazendo inscrições culturais em suas tampinhas "cultura na tampa" (id., 1986, p. 63-64), trabalhou, também, no Boqueirão - espécie de bairro em que habitam pessoas disformes, aleijadas e miseráveis: doentes, esfomeados, subnutridos, miseráveis, famílias cheias de filhos (id., 1986, p. 126) admitindo ou não moradores de acordo com suas deformações, pois estas servirão para atrair o turismo, num contexto que não apenas explora o pobre, mas espetaculariza a pobreza.

Então Zé conhece Rosa no restaurante em que ela trabalhava de cozinheira, o Giratório, e se casa com ela. Rosa sonhava com casamento, casa própria e em constituir uma família. Em razão dessa formação e desse pensamento pequenoburguês tradicionalista, Rosa acaba colaborando com o fato de José acabar entrando no universo da criminalidade. Ela dizia que o marido deveria ter o papel de provedor de tudo isso que ela sonhava enquanto ela deveria deixar de trabalhar para viver em prol do lar. Para tanto, Rosa insistia que Zé largasse o emprego no Boqueirão e fosse procurar emprego de gente, decente, de futuro, para fazer carreira, conseguir dinheiro e prover segurança para a família, conquistando, assim, a desejada (por Rosa) vida medíocre e hipócrita daqueles da pequena-burguesia (id., 1986, p. 89, 118). José, que não tinha condições de promover o que Rosa queria, oprimido de todas as formas pela esposa, pelo sistema e por toda conjuntura nele envolvida, vê, como única alternativa, começar a roubar: "Se eu não tenho dinheiro, se não tenho emprego para ganhar dinheiro. Roubo" (id., 1986, p. 132).

No transcorrer dos fragmentos, o Boqueirão, o qual tinha recebido investimentos do governo que rapidamente percebeu a lucratividade da pobreza (id., 1986, p. 87), é interditado pelo próprio regime militar, durante a "operação pente-fino", porque o povo estava se divertindo demais (id., 1986, p. 92). Isso faz com que todos os pobres, seus moradores, fossem esmolar na cidade: "a massa de desempregados 


\section{$($ ("intire}

passou para a cidade. Pediam esmolas nos viadutos, portas de igrejas, praças, cinemas" (id., 1986, p. 160).

Levado pelas circunstâncias, assaltando para manter a vida que Rosa sonhava, José se pergunta constantemente sobre o porquê de se fazer tudo aquilo (casar, sustentar esposa que não trabalha, comprar casa própria, fazer seguro de vida, constituir família) sem compreender suas próprias atitudes (id., 1986, p. 132, 158), como foi levado àquilo e como os assaltos passaram a ser prazerosos, inclusive quando matava suas vítimas. Gostando do que sentia quando assaltava e/ou matava, acaba descobrindo os comuns, grupo de guerrilheiros que agia, assaltando e matando (quando necessário), sob uma ideologia combativa contra o governo. José acaba se juntando a eles depois que Gê, o líder do grupo, o convence de que assaltar e matar simples e puramente por assaltar e matar não fazia sentido: cometer tais crimes solitariamente, sem um motivo coletivo, não tinha razão de ser (id., 1986, p. 178-179, 184-190).

No entanto, os assaltos/mortes por necessidade e, depois, por prazer, praticados por José, assim como muitos dos saques e assaltos a bancos não praticados por José, nem pela guerrilha, ao longo da narrativa, parecem traduzir um sentimento de raiva/ódio/vingança contra a violência sofrida pela miséria, pela exploração, pela desigualdade social: “(...) eu odiava porque o ódio é o amor e é preciso odiar e não amar, é preciso romper e violentar o mundo, se a gente quiser começar de novo alguma coisa boa, melhor" (id., 1986, p. 81) ou "Sei quem sou e o que posso. Só queria que ele tivesse levado essa raiva. Que ele tirasse o arame farpado que tenho na garganta" (id., 1986, p. 32). Esse sentimento parece constante, inclusive na construção linguística que estrutura o texto, em razão do fragmentarismo, da escrita telegráfica, sincopada.

Em muitos momentos, tal sentimento, assim como a violência praticada e sofrida, ganha forma de testemunho, emitido tanto por seus agentes como por suas vítimas, em diversos contextos diferentes: de tortura, de assaltos, etc. Por exemplo: 


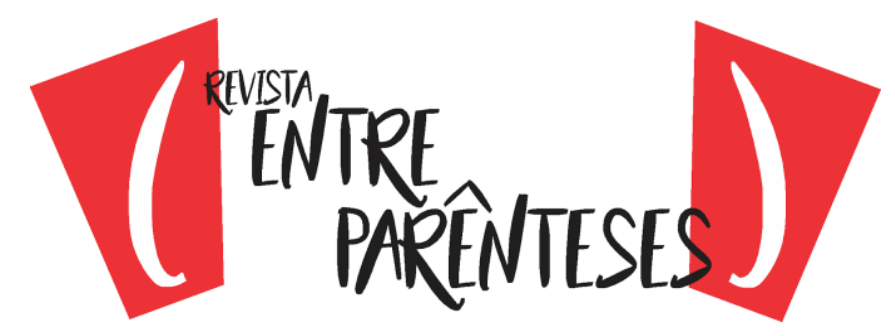

Coloquei o revólver na cara do homem. Ele ia andando e embaixo do poste gritei. Ele se virou e deu com o revólver. Imaginou que era assalto. Levantou a mão e ficou esperando que eu dissesse o que fazer. Só pensei: "É uma bosta". Um tiro em cheio. O rosto se abriu, o sangue não saiu imediatamente. Deu para ver a brecha na testa, a pele dilacerada, 0 osso partido, miolos. Aí o sangue escorreu, encheu a cara, o homem caiu. Não senti medo. Atirei e fiquei olhando. Sabia que ia me lembrar. Era a primeira vez e eu tinha prometido observar, com cuidado. Assoprei o cano do revólver. Era um gesto que eu não queria fazer, mas senti vontade e assoprei. Sou um mocinho (id., 1986, p. 156).

Ao mesmo tempo em que há esse impulso violento de ódio, há, também, uma certa falta de perspectivas do que viria a ser o futuro, de como melhorar a vida, que paira sobre José, sobre a massa de excluídos, de miseráveis, sobre todos que vão levando a vida, sobrevivendo à tecnocracia e à ditadura militar (id., 1986, p. 83, 114$115,157)$. Esse tédio se traduz em manifestações sintomáticas de certa abulia geral.

Enquanto isso, o progresso: fábricas, metrô, automóveis, construções, estradas, viadutos, rodovias, os avanços da ciência, propagandas, ruídos, lojas, bancos, investimentos, o cinema, o rádio, a TV, as telenovelas, repressão, censura, proibições, determinações oficiais arbitrárias do governo, o desenvolvimento. Em contrapartida:

José pegou um pacote de livros. Vendeu, num sebo. Foi comer. Vivia de misto, iogurte, laranjas. Estava louco para brigar. Fazia dez dias que não brigava. Andava apático, se estranhava. Precisava roubar um sapato, o seu ia furar. Parou numa casa de discos, ficou hora e meia ouvindo. $O$ vendedor, incomodado. A música da loja se confundia - apitos brecadas - guinchos - martelos - música -bater de portas - frases de camelôs - burburinho de passos - máquina de escrever - mudanças de marchas - bate estacas - xingos-vidros quebrados - vozes: ? para onde ir ?procurar emprego. Vou pra zona. Entrou no cinema, gongo, tela se abrindo (...).

THE END, os olhos de José ardiam, a dor de cabeça, o cinema cheirava mal. Passou num bar, água com açúcar / Levei um bruta susto, quase fui atropelado, preciso me acalmar um pouco /. Água com açúcar mata fome, já dava para dormir, se ele fosse correndo para a casa. Pegou o ônibus, fez que se lembrou, estou sem dinheiro, posso descer aqui, já tinham passado três pontos, o cobrador abriu a porta detrás. José 


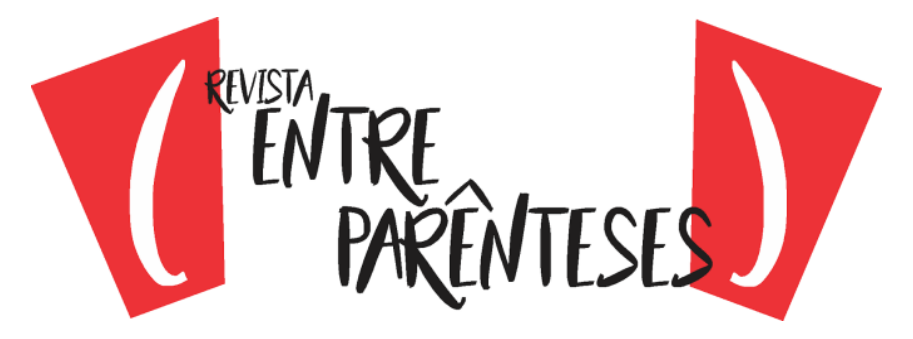

esperou o outro ônibus, estou sem dinheiro, posso descer aqui. Esperou mais um; quatro pontos adiante, um novo; e depois conseguiu passar cinco sem descer; quando faltavam dois para o apartamento, caminhou (id., 1986, p. 44).

E os imigrantes - do Norte, do Nordeste, do exterior - "descem, descem, gado nos vagões, gôndolas vêm dos altiplanos, fogem, as roupas impregnadas de pó de cobre, velhos aos 40 anos, subnutridos, doentes, mirrados, mulheres mirradas, filhos esfomeados, enchem as salas da imigração" (id., 1986, p.151):

Todos os dias chegam trabalhadores à procura de emprego. Sempre há vagas nas obras dos Monumentos Nacionais. Dizem (não se confirma) que quase todos os dias morrem operários em acidente, pela falta de segurança e pela pressa com que o governo pretende terminar a obra, a fim de comemorar o Décimo Aniversário da Revolução que tirou o país das mãos dos comunistas.

O costarriquenho conseguiu o emprego, porque aceitou o Terçomínimo.

É isso, meu caro, se quiser. É o salário para estrangeiro. Está baixando muito em nosso país, ultimamente? O que é que há por lá.

Terçomínimo: uma das três partes do salário mínimo. (id., 1986, p.51-52)

Tudo isso vai acontecendo em um clima claustrofóbico, uma vez que, fechados nessa sociedade sem saída, nesse sistema repressivo, "a vida virava Zero" (id., 1986, p. 122). O desemprego, a concentração de renda na mão dos mais ricos - da classe empresarial-, a exploração do trabalho, salários cada vez mais baixos, o imperialismo e a incitação ao consumo, a desigualdade social, a repressão (política, ideológica, moral, educacional, social, etc.) promovida pelo governo e ter de sobreviver a tudo isso, vivendo numa cidade grande, com trabalhos temporários, bicos, mantendo família e casa, lutando contra a miséria. Tudo isso faz de "Zero" um romance cuja história é o sufoco impingido por uma opressão labiríntica da qual não se consegue sair. Num cenário político-econômico repressivo e violento, as pessoas vão tentando viver a vida, driblando e se adequando à situação.

De acordo com Pellegrini (1996, p. 140), a miséria é o verdadeiro "pano de fundo" de Zero, que envolve a ação das personagens e praticamente as determina. 


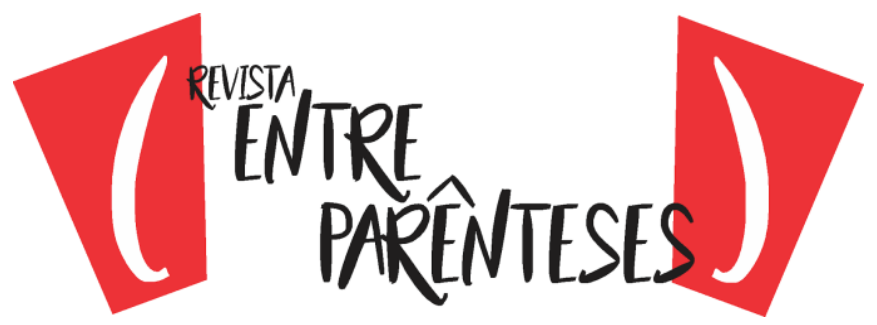

Tanto dentro como fora do Boqueirão, miséria, violência e anormalidade coexistem, se imiscuem, se imbricam e se implicam: num círculo vicioso (Zero!), resultam sempre e progressivamente em mais violência, mais miséria, mais deformidade (id., 1996, p.142). Gradativamente, o romance vai transformando a miséria-pobreza em miséria-humana a qual "passa a ser um elemento 'normal', integrado estruturalmente ao corpo da sociedade que se retrata na ficção" (id., 1996, p. 141). Segundo Pellegrini (1996, p. 129), ademais, "Zero" é um romance cujo espaço "explode em violência": "convulsões agônicas de agressividade explícita no quotidiano dos personagens, no meio em que circulam, povoado de anormais, doentes e aleijados"; na política empreendida pelo governo militar; no bombardeio atordoante dos meios de comunicação; no consumismo impulsivo que tenta suprir um vazio não preenchível; no tecnicismo; etc.: "O anel de Zero, ao mesmo tempo ponto de partida e de chegada, elo intacto e constrangedor, envolve tudo num círculo inamovível de violência e perplexidade" (id., 1996, p. 129) e "os personagens, quase todos alienados e passivos, não conseguem romper esse círculo, dentro do qual se debatem, sem saída, como num labirinto". Os recursos estéticos/linguísticos empregados no romance, por fim, não são preponderantes uma vez que atendem uma necessidade gerada pelo próprio tema (ou pelos próprios temas) do texto (id., 1996, p. 131). O que, parece, iguala o ético e o estético uma vez que a linguagem, i.e., o segundo, serve ao primeiro, delineando o clima e o tom, bem como ressaltando a problemática, a reflexão, proporcionada pela ficção.

Regina Dalcastagné (1996, p. 69-71) diz que a miséria seria uma das protagonistas de "Zero" porque além de voz, ela tem corpo (composto pelos vários corpos disformes que habitam um país da América Latíndia e nele se arrastam esmolando emprego e comida). Uma miséria que, ao ser exposta, se transfigura à medida que se espetaculariza: "põe-se à venda a própria anulação do homem". Por isso, segundo a pesquisadora, não poderia ser outra a forma de mediação de José com o mundo, senão a violência. Porque "como indivíduo em confronto com o universo, ele decide agir sozinho, destruindo aquilo que o impede de fazer algo contra o que o 


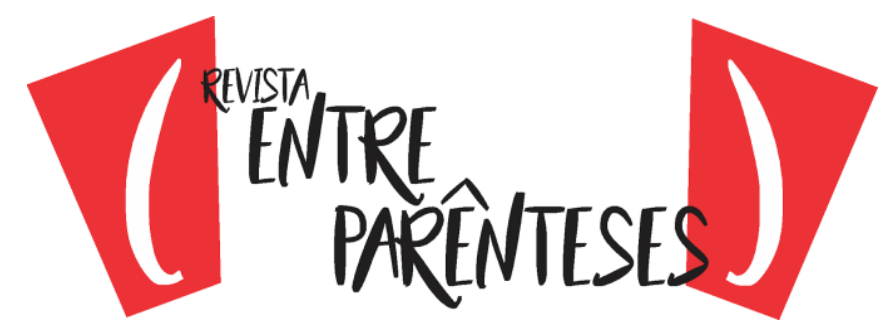

oprime - o medo". A violência de José, portanto, para Dalcastagné, é calculada e individual: ele não tem consciência política para lutar contra um regime ditatorial, mas instintivamente ele tenta sobreviver a todas as opressões imbricadas no e resultantes do mesmo regime.

\section{Conclusão}

Diante de tudo aqui ora exposto, parece oportuno postularmos uma revisão (que em certa medida já vem acontecendo lentamente) do que consideramos literatura. Necessita-se de uma nova concepção do termo que esteja livre do ranço estruturalista, formalista, historicista, sociológico, culturalista; livre de perspectivas reducionistas e redutoras do fenômeno literário a meras questões estéticas e/ou exclusivamente sociais.

Isso implicaria, por via de consequência, um questionamento do cânone (também já em curso, talvez não pelos melhores argumentos) enquanto algo consolidado e estático em face de uma outra noção que o expanda, tornando-o mais dinâmico e em estado permanente de (des)construção, na medida em que a crítica precisa estar mais aberta à desmistificação da estagnação da produção literária contemporânea e disposta a ler/analisar o que tem sido escrito ultimamente. Gesto que propõe tirar da margem várias vozes que ficaram proibidas de serem literatura por carregarem consigo a necessidade de tentar, pelo menos, se aproximar e, "quiçá", superar a "alta literatura" produzida por um João Guimarães Rosa ou por um Machado de Assis, bem como por uma Clarice Lispector.

Isso significaria uma democratização do acesso ao cenário literário que levaria a consolidar um papel democrático da crítica de continuar cumprindo sua função, não apenas em relação aos que "merecem" serem lidos/analisados por ela, mas a quem produz, publica e circula se intitulando literatura. Trata-se de proposta polêmica. Estamos longe de alcançar respostas, uma vez que, como já dito, isso implica 


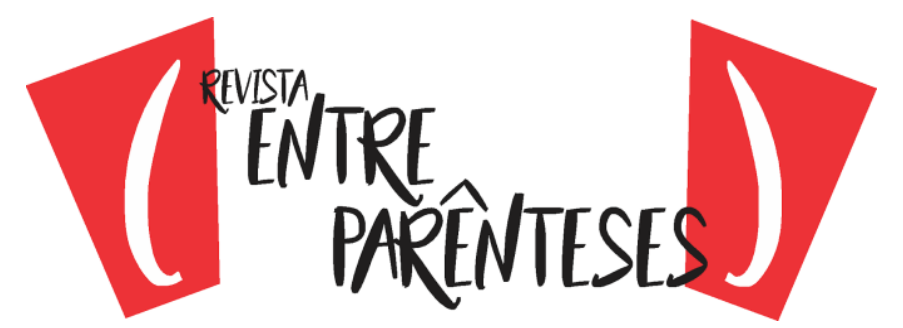

revermos o que define um texto como literário, para além dos preceitos clássicos do gosto, do belo, do estético, do exclusivamente histórico e social. No entanto, se faz necessário ouvir os protestos vindos das margens, em todos os sentidos. Se faz necessário aprender a ouvir todas as pessoas, sem rótulos, sem estigmas, sem considerá-las subalternas, porque todos devem igualmente poder falar. $E$ a literatura, a partir disso, vai se refazendo por meio dessa crítica democrática.

Da mesma maneira, porém, não se deve desfazer da literatura já consolidada, colocando em xeque sua legitimidade e representatividade, apenas porque foi feita por uma pessoa e não por outra, apenas porque foi feita em determinadas condições e não em outras, apenas porque foi feita em determinados tempos e espaços e não em outros. Tudo tem valor e importância mimético-representacional (PELLEGRINI, 2007; 2009; LIMA, 2014; ISER, 2013) e talvez deva ser esse o caminho para se alcançar uma análise teoricamente crítica e democrática. Dessa forma, é necessário que sejamos flexíveis a ponto de, por exemplo, considerarmos "Zero" como uma obra que, de acordo com seu tempo, espaço, condições de produção e de autoria, representa bem um drama de uma classe popular.

De acordo com as características da literatura marginal contemporânea apontadas por Patrocínio, "Zero" é, portanto, um texto potente e potencialmente político, que, indiretamente, por meio de seu enredo e de suas significações/leituras possíveis denuncia os absurdos e arbitrariedades do momento, bem como suas consequências, por exemplo a miséria. Assim o faz ficcionalizando o cotidiano de pessoas que vivem numa grande cidade sob suas contradições/contrastes e, consequentemente, promovendo o agenciamento político do leitor que adquire consciência de olhar apurado e perspectivado em relação à existência daquelas situações, problemas, conflitos e pessoas. Ele mostra diversas face da violência (social, psicológica, política, gratuita e prazerosa, etc.), trazendo testemunhos de suas vítimas e de seus agentes, bem como ecoando um sentimento de vingança (individual e social, contra o sistema que se consolidava, contra seus autores, os autores da desigualdade social, e contra os 


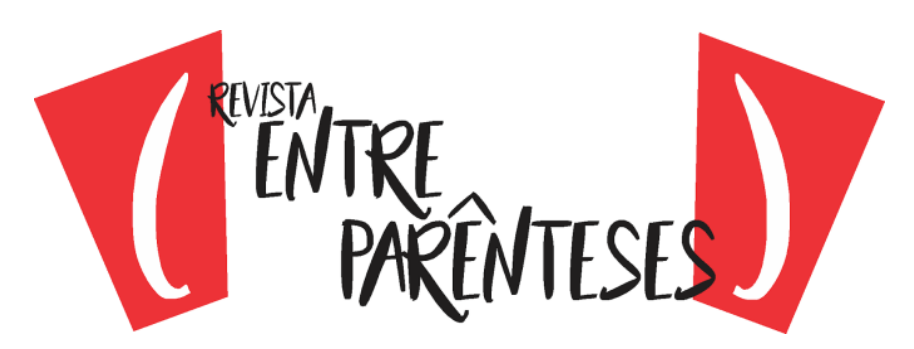

produtores da miséria) que ela gera. A dicção violenta (a linguagem telegráfica, sincopada, cheia de ruídos, interrompida, fragmentada, de pontuação descompassada, que remete à oralidade em todos os sentidos), assim como o tom escatológico, por vezes naturalista, desmontam a falsa moral e a hipocrisia pequeno-burguesa personificada, principalmente, na figura de Rosa - gerada pelo sistema em consolidação. Há a presença do princípio ético regulador que explora, em todas as direções, os temas (da violência, da miséria, da ditadura, da indústria cultural, etc.), no entanto, em equilíbrio com o trabalho dos recursos estéticos. $E$ todas as narrativas que compõem "Zero" parecem integrar um enunciado que diz sobre pessoas de qualquer cidade grande, de qualquer país da América Latina, sobretudo aqueles que passaram, também, por regimes ditatoriais, tecendo um grande discurso coletivo de resistência à opressão social, econômica, política, cultural, etc.

"Zero", por isso, não é mais marginal que qualquer outro romance da Literatura Marginal Contemporânea. Assim como este não é, da mesma forma, mais marginal que aquele. E nem um tanto quanto o outro. Eles fazem, igualmente, parte do que se chama Literatura. E a crítica democrática, que se dispõe a lê-los e analisá-los, estará sempre fundamentando cientificamente opiniões. Não há quem diga que a crítica é uma outra ficção?

A grande questão talvez seja que ninguém deveria estar à margem (cultural, artística, política, social, econômica, no espaço, etc). Mas, em tempo de radicalizações, de sórdidos preconceitos, resta mesmo dar o grito, de onde quer que se esteja, em prol de uma luta para que o homem não perca (e não se perca) o que o faz humano.

\section{REFERÊNCIAS}

BOSI, Alfredo. A literatura e os excluídos. In: Literatura e resistência. São Paulo: Companhia das Letras, 2002, p. 257-269.

BRANDÃO, Ignácio de Loyola. Zero. São Paulo: Clube do Livro, 1986. 


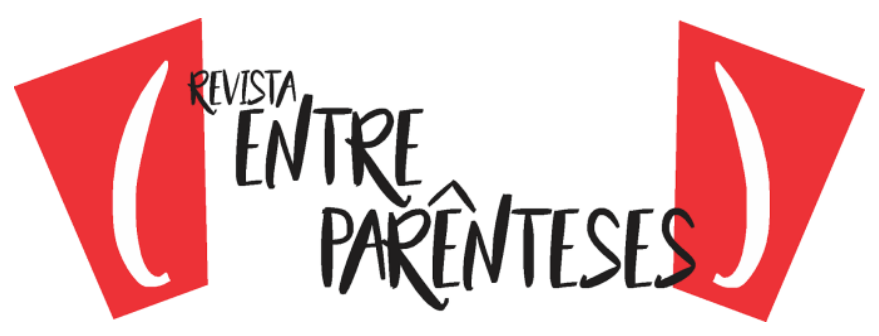

CESAR, Ana Cristina. Malditos marginais hereges. In: Crítica e tradução. São Paulo: Editora Ática, 1999, p.204-212.

CRUZ, Adélcio S. Introudção. In: Narrativas contemporâneas da violência: Fernando Bonassi, Paulo Lins e Ferrez. 2009, 228f. Tese (doutorado em Letras - Literatura Comparada), Faculdade de Letras, Universidade Federal de Minas Gerais - UFMG, Belo Horizonte, 2009, p. 10-27. Disponível em: <http://www.bibliotecadigital.ufmg.br/dspace/bitstream/handle/1843/ECAP7V3GHU/tese__ad_Icio_de_sousa_cruz.pdf;jsessionid=59AF872492893EA6199C0B9 A61F2E392? sequence $=\overline{1}$. Acesso em: abril de 2017

DALCASTAGNÉ, Regina. O espaço da dor: o regime de 64 no romance brasileiro. Brasília: Editora da Universidade de Brasília, 1996.

FERRÉZ. Terrorismo Literário. In: Literatura marginal: talentos da escrita periférica. Rio de Janeiro: Agir, 2005.

GONZAGA, Sergius. Literatura marginal. In: Crítica literária em nossos dias e literatura marginal. Porto Alegre: Editora da UFRGS, 1981, p; 143-153.

ISER, Wolfgang. O fictício e o imaginário: perspectivas de uma antropologia literária. Rio de Janeiro, EdUERJ, 2013.

LIMA, Luiz Costa. Mímesis: desafio ao pensamento. Florianópolis, Ed.UFSC, 2014.

PATROCÍNIO, Paulo R. T. Literatura marginal, uma literatura feita por minorias. In: Escritos à margem: a presença de autores de periferia na cena literária brasileira. Rio de Janeiro: 7 letras, 2013, p. 23-64.

PELLEGRINI, Tânia. Gavetas vazias: ficção e política nos anos 70. São Carlos: EdUFSCar - Mercado das letras, 1996.

- Realismo: a persistência de um mundo hostil. In: Revista Brasileira de Literatura Comparada, Rio de Janeiro, v.11, n.14, p. 11-36, 2009. Disponível em: $<$ http://revista.abralic.org.br/index.php/revista/article/view/212/215> Acesso em: 02 abr. 2017.

155, $2007 . \quad$ Disponível em: $<$ http://revistaseletronicas.pucrs.br/ojs/index.php/fale/article/view/4119/3120> Acesso em: 02 abr. 2017. 


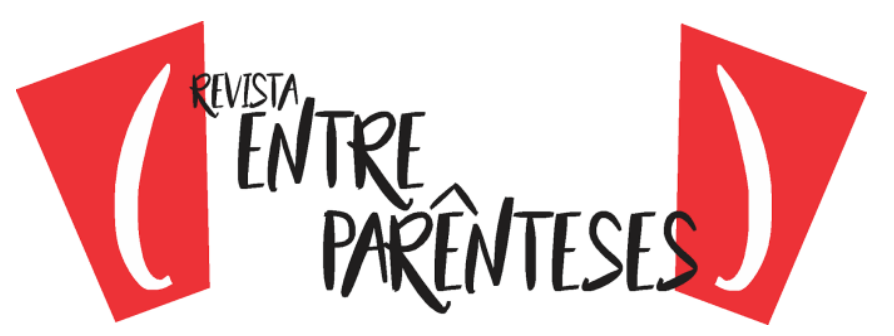

ROCHA, João C. de Castro. A guerra de relatos no Brasil contemporâneo. Ou: "a dialética da marginalidade". Letras, Santa Maria, n.32, p. 24-70, jan-jun, 2006. Disponível em: <https://periodicos.ufsm.br/letras/article/view/11909/7330>. Acesso em: 16 abr. 2017.

SUSSEKIND, Flora. Literatura e vida literária - Polêmicas, diários \& retratos. Rio de Janeiro: Jorge Zahar Ed., 1985.

Recebido em: 21/04/2018

Aceito em: 21/11/2018 